\title{
PEMANFAATAN KITOSAN KULIT UDANG DENGAN PENAMBAHAN EKSTRAK DAUN KESUM SEBAGAI PENGHAMBAT BAKTERI PADA EDIBLE COATING
}

\section{Utilization of Shrimp Skin Chitosan with Addition of Kesum Leaf Extract as Bacterial Inhibitor on Edible Coating}

\author{
Retno Budi Lestari ${ }^{1 *}$, Achmad Mulyadi Sirojul Munir², Yuli Arif Tribudi ${ }^{3}$ \\ ${ }^{1,3}$ Program Studi Peternakan - Fakultas Pertanian - Universitas Tanjungpura \\ Jl. Prof. Dr. H. Hadari Nawawi - Pontianak - Kalimantan Barat 78124 \\ ${ }^{2}$ Program Studi Manajemen Sumberdaya Perairan - Fakultas Pertanian - Universitas Tanjungpura \\ Jl. Prof. Dr. H. Hadari Nawawi - Pontianak - Kalimantan Barat 78124 \\ *Penulis Korespondensi: email retno_bl@yahoo.com
}

Disubmit: 24 Agustus 2018 Direvisi: 13 November 2018 Diterima: 27 Desember 2018

\begin{abstract}
ABSTRAK
Penelitian bertujuan untuk mengetahui pengaruh daya hambat edible coating kitosan - pati biji durian dengan penambahan ekstrak daun kesum terhadap pertumbuhan bakteri Staphylococcus aureus dan Escherichia coli. Rancangan penelitian yang digunakan adalah Rancangan Acak Lengkap (RAL) dengan perlakuan konsentrasi ekstrak daun kesum $\mathrm{K}_{0}=0.00 \%$; $\mathrm{K}_{1}=0.20 \%$; $\mathrm{K}_{2}=0.40 \% ; \mathrm{K}_{3}=0.60 \% ; \mathrm{K}_{4}=0.80 \% ; \mathrm{K}_{5}=1.00 \% ; \mathrm{K}_{6}=1.20 \%$, dan $\mathrm{K}_{7}=1.40 \%$. Edible coating dibuat dengan formula dasar pati biji durian $3.00 \%$; kitosan $0.80 \%$; gliserol $0.60 \%$. Parameter yang diamati adalah daya hambat menggunakan metode paper disk. Hasil penelitian menunjukan bahwa daya hambat edible coating pati biji durian - kitosan dengan penambahan ekstrak daun kesum berpengaruh sangat nyata $(\mathrm{p}<0.01)$ terhadap pertumbuhan bakteri Staphylococcus aureus maupun Escherichia coli. Nilai daya hambat edible coating dengan penambahan ekstrak daun kesum terhadap bakteri Staphylococcus aureus antara 3.432 - $4.344 \mathrm{~mm}$, sedangkan bakteri Escherichia coli antara 2.233-3.596 mm. Daya hambat terhadap bakteri yang tertinggi adalah ekstrak daun kesum $1.40 \%$ sebesar $4.344 \mathrm{~mm}$ (Staphylococcus aureus) dan $3.596 \mathrm{~mm}$ (Escherichia coli). Semakin tinggi konsentrasi ekstrak daun kesum, terbukti bahwa semakin tinggi daya hambat terhadap bakteri Staphylococcus aureus dan Escherichia coli
\end{abstract}

Kata kunci: Daya Hambat; Daun Kesum; Escherichia coli; Kitosan; Staphylococcus aureusi

\begin{abstract}
The aim of this research is to determine the inhibitory effect of edible coating chitosan from durian seed starch by the addition of Kesum leaf extract toward the growth of Staphylococcus aureus and Escherichia coli. This experimental design used is a Completely Randomized Design (CRD) treated by concentration of Kesum leaf extract $(K): K_{0}=0.00 \%, K_{1}=0.20 \%, K_{2}=0.40 \%, K_{3}=0.60 \%, K_{4}=0.80 \%, K_{5}=1.00 \%$, $K_{6}=1.20 \%$, and $K_{7}=1.40 \%$. The formulation of edible coating consist of $3.00 \%$ durian seed starch; $0.80 \%$ chitosan and $0.60 \%$ gliserol. The observed parameter is inhibitory effect using paper disk method. The result showed that the inhibition of edible coating chitosan from durian seed starch treated with the addition of Kesum leaf extract has significantly effect $(p<0.01)$ on inhibition the growth of Staphylococcus aureus and Escherichia coli. The inhibitory effect of edible coating by adding Kesum leaf extract to S. aereus growth ranged 3.432-4.344 mm, while in Escherichia coli ranged 2.233-3.596 mm. The highest of inhibitory effect on bacteria was 1.40\% Kesum leaf extract; $4.344 \mathrm{~mm}$ in Staphylococcus aureus and $3.596 \mathrm{~mm}$ in Escherichia coli. The higher the concentration of Kesum leaf extract, the greater the inhibition of Staphylococcus aureus and Escherichia coli
\end{abstract}

Keywords: Chitosan, Escherichia coli; Kesum Leaf; Power Inhibition; Staphylococcus aureus 


\section{PENDAHULUAN}

Edible coating adalah bentuk lain dari edible packaging, yaitu lapisan bahan pangan yang terbuat dari bahan yang dapat dimakan. Edible coating termasuk salah satu kemasan ramah lingkungan yang saat ini masih terus dikembangkan, terutama tentang jenis biopolimer yang digunakan sebagai bahan komposit atau campuran. Bahan pembuatan edible coating yang potensial adalah berbasis pati, salah satunya adalah pati biji durian. Kombinasi antara pati dengan biopolimer hidrofobik dapat digunakan untuk memperbaiki kekurangan kemasan berbahan pati salah satunya adalah kitosan (Ban et al., 2005).

Kitosan merupakan biopolimer dari D-glukosamin yang disintesis dari proses deasetilasi kitin dengan menggunakan basa kuat (Lee et al., 2001). Kitosan adalah biopolimer yang bersifat hidrofobik, sehingga kitosan sangat cocok jika digunakan sebagai bahan komposit pembentuk lapisan tipis (film) bersama dengan pati yang bersifat hidrofilik. Kitosan juga merupakan salah satu bahan pengawet alami yang dapat disintesa dari kulit udang, karena mempunyai kemampuan menghambat pertumbuhan bakteri. Oleh karena itu edible coating dengan bahan baku komposit pati dan kitosan akan meningkatkan fungsinya sebagai pengemas, selain melindungi bahan pangan juga mengandung bahan pengawet (Hardjito, 2006; Costa et al., 2018; Hajji et al., 2018; Chakravartula et al., 2019).

Edible coating komposit kitosan dan pati biji durian selain sebagai bahan pembentuk lapisan tipis/film, juga dapat diperkaya dengan bahan alami lain yang mempunyai aktivitas antioksidan dan antimikroba untuk meningkatkan kemampuannya sebagai pengemas. Daya hambat kitosan dapat pula ditingkatkan dengan cara mengkombinasikan dengan bahan lainnya yang diketahui juga memiliki kemampuan menghambat pertumbuhan bakteri. Pada dasarnya edible coating juga dapat berfungsi sebagai pembawa (carrier) aditif makanan, seperti agen anti pencoklatan, antimikrobia, pewarna, penambah flavor, nutrisi, dan bumbu (RojasGrau et al., 2009).

Beberapa penelitian sebelumnya telah dilakukan oleh Chi et al. (2006) yaitu menggunakan bahan alami oregano oil yang ditambahkan ke dalam larutan bahan pembuatan film kitosan ternyata mampu meningkatkan penghambatan kitosan terhadap bakteri patogen pada produk daging. Demikian juga Maizura et al. (2008) telah menambahkan minyak atsiri daun serai sebesar $0.40 \%$ pada edible film pati sagu sebagai bahan antimikroba mampu menghambat pertumbuhan bakteri Escherichia coli dan Salmonella enteritidis. Beberapa bahan alami yang telah digunakan sebagai edible packaging sosis antara lain oleoresin daun jeruk purut (Citrus hystrix DC.) (Pudil et al., 1998; Utami et al., 2015).

Salah satu bahan alami yang dapat dimanfaatkan sebagai antimikrobia pada edible coating adalah daun kesum. Daun kesum (Polygonum minus Huds) adalah tanaman endemik Kalimantan Barat, yang mempunyai rasa dan aroma khas. Tanaman ini dikenal oleh masyarakat lokal sebagai bumbu "Bubur Padas" yang merupakan makanan khas Kalimantan Barat. Senyawa aktif yang terdapat dalam daun kesum bersifat sebagai antimikrobia. Wibowo (2009) telah melakukan skrining fitokimia ekstrak daun kesum menggunakan fraksi metanol mengandung komponen senyawa golongan fenolik, terpenoid-steroid, flavonoid dan alkaloid (Wibowo, 2009). Berdasarkan penelitian Fitriana et al. (2014) bahwa senyawa mayor yang terdapat dalam minyak atsiri daun kesum adalah n-dodekanal 31.00\%, n-dekanal $16.88 \%$, n-dodekanol 6, $12.00 \%$, 8-bromo tetrametil naftalen $4.63 \%$, Trans-( $\beta$ )-caryopilen $3.37 \%$.

Dekanal dan dodekanal merupakan senyawa turunan aldehida, yang memberikan karakterisitik rasa dan aroma khas kesum. Wibowo (2009) telah meneliti bioaktivitas antimikroba minyak atsiri kesum yang diperoleh dari fraksi metanol dan dietil eter dari ekstrak metanol daun kesum mampu menghambat pertumbuhan bakteri Escherichia coli dan Basilus subtilis. Penggunaan ekstrak daun kesum sebagai senyawa antimikrobia pada edible coating diharapkan dapat menghambat pertumbuhan bakteri beberapa jenis mikrobia pathogen, antara lain bakteri Escherichia coli dan Staphylococcus aureus, sehingga diharapkan akan dapat meningkatkan fungsinya sebagai pengemas pangan. Oleh karena itu, penelitian ini bertujuan untuk mengetahui pengaruh daya hambat edible coating kitosan-pati biji durian dengan penambahan ekstrak daun kesum terhadap pertumbuhan bakteri Staphylococcus aureus dan Escherichia coli. 


\section{METODE}

Penelitian ini telah dilaksanakan di Laboratorium Peternakan Fakultas Pertanian Universitas Tanjungpura Pontianak, pada bulan Mei - November 2017. Alat-alat yang digunakan adalah timbangan analitik, erlenmeyer, gelas ukur, hot plate stirer, batang pengaduk, tabung reaksi, cawan petri, gelas piala, autoklaf, kompor, kawat ose, lampu bunsen, kapas, korek api, alu dan mortar, mikro pipet, laminar airflow (B-One), inkubator (Memmert), evaporator (Buchi R-205), pinset, lemari pendingin, penggaris, jangka sorong, sarung tangan, dan kamera.

Bahan-bahan yang digunakan adalah kulit udang, pati biji durian, daun kesum, gliserol, etanol, aquades, media NA (Nutrient Agar), isolate bakteri Escherichia coli dan Staphylococcus aureus yang diperoleh dari Program studi Farmasi Universitas Tanjungpura, paper disk, kertas saring, garam fisiologis, aluminium foil, kertas label, kertas cakram $10 \mathrm{~mm}$, dan silica gel.

Penelitian menggunakan metode eksperimen dengan menggunakan Rancangan Acak Lengkap (RAL) yang terdiri dari 8 perlakuan yaitu konsentrasi ekstrak daun kesum dengan taraf $0.00 \%\left(\mathrm{~K}_{0}\right)$ sebagai kontrol; $0.20 \%\left(\mathrm{~K}_{1}\right) ; 0,40 \%\left(\mathrm{~K}_{2}\right) ; 0.60 \%\left(\mathrm{~K}_{3}\right) ; 0.80 \%$ $\left(\mathrm{K}_{4}\right) ; 1.00 \%\left(\mathrm{~K}_{5}\right) ; 1.20 \%\left(\mathrm{~K}_{6}\right)$; dan $1.40 \%\left(\mathrm{~K}_{7}\right)$, masing-masing dengan 3 ulangan. Variabel penelitian yang diamati adalah daya hambat edible coating dengan penambahan ekstrak daun kesum terhadap pertumbuhan bakteri Escherichia coli dan Staphylococcus aureus.

Pembuatan kitosan menggunakan metode Rahayu dan Purnavita (2004) melalui 3 tahap yaitu deproteinasi (menggunakan $\mathrm{NaOH} 2 \mathrm{~N}$ ), demineralisasi (menggunakan $\mathrm{HCl} 1.50 \mathrm{~N}$ ) sampai dengan terbentuk kitin. Setelah itu kitin di deasetilasi (menggunakan $\mathrm{NaOH} 50.00 \%$ ) sampai diperoleh padatan kering kitosan.

Pembuatan pati biji durian menggunakan metode pengeringan dan ekstraksi pati biji durian (Amid dan Mirhosseini, 2012; Ho et al., 2015). Ekstraksi daun kesum dibuat dengan menggunakan metode maserasi dengan pelarut etanol. Daun kesum rajang segar $( \pm 0.50 \mathrm{~cm})$ dan ditimbang, selanjutnya dimaserasi (direndam) dengan pelarut etanol 96.00\% (E-Merck) pada suhu ruang selama 24 jam. Perbandingan bahan dengan pelarut sebesar 1:50. Penyaringan filtrat dari ampas, kemudian dimaserasi kembali dengan etanol selama 24 jam lagi. Hal ini dilakukan secara terus-menerus sampai $4 \times 24$ jam. Pemisahan pelarut dari filtrat hasil ekstraksi dilakukan menggunakan rotary vacum evaporator dengan suhu $80^{\circ} \mathrm{C}$ dan kecepatan $100 \mathrm{rpm}$ dan proses ini dihentikan setelah pelarut etanol teruapkan seluruhnya dengan indikasi etanol tidak menetes lagi, serta didapatkan ekstrak.

Formula dasar larutan edible coating dibuat sesuai dengan metode yang mengacu pada Lestari dan Maherawati (2014) dengan modifikasi, yaitu $0.80 \%$ kitosan: $3.00 \%$ pati biji durian $0.60 \%$ gliserol dari $120 \mathrm{ml}$ aquades. Semua bahan dilarutkan dan dipanaskan pada suhu $70^{\circ} \mathrm{C}$ hingga tergelatinisasi. Setelah larutan dingin, dilakukan penambahan ekstrak daun kesum sesuai dengan perlakuan dan diaduk rata menggunakan hot plate magnetic stirrer.

Pengujian aktivitas antimikrobia larutan edible coating kitosan-pati biji durian dengan penambahan ekstrak daun kesum dilakukan dengan menggunakan metode cakram atau paper disk (Permatasari et al., 2013), yaitu dengan mengamati zona hambat berupa diameter zona bening yang terbentuk. Inokulum dari masing-masing bakteri Escherichia coli dan Staphylococcus aureus diambil secara aseptik sebanyak $1 \mathrm{ml}$ dari medium NB (Nutrient Broth) dan dituangkan ke cawan petri yang sudah berisikan medium NA (Nutrien Agar). Setelah itu kertas cakram yang berukuran $\pm 10 \mathrm{~mm}$ dicelupkan ke dalam larutan edible coating yang sudah ditambahkan ekstrak daun kesum dengan konsentrasi yang berbeda yaitu $0.00 \%$ (tanpa ekstrak daun kesum), $0.20 \%, 0.40 \% 0.60 \%$, $0.80 \%, 1.00 \%, 1.20 \%$, dan $1.40 \%$. Setelah itu, kertas cakram diletakkan di atas cawan petri yang masing-masing sudah berisi medium yang mengandung bakteri Staphylococcus aureus dan Escherichia coli, dengan menggunakan pinset. Setelah itu diinkubasi selama 24 jam pada temperatur $37^{\circ} \mathrm{C}$, lalu diamati dan diukur diameter zona bening yang merupakan zona hambatannya sampai hari kedua.

Besarnya zona hambat dari masingmasing perlakuan yang diperoleh ditabulasi dan dianalisis menggunakan analisis ragam ANOVA. Apabila ada perbedaan pengaruh antar perlakuan, maka dilanjutkan dengan uji jarak berganda Duncan's. 


\section{HASIL DAN PEMBAHASAN}

Berdasarkan hasil penelitian edible coating pati biji durian-kitosan yang ditambahkan berbagai konsentrasi ekstrak daun kesum menunjukkan pengaruh yang sangat nyata $(\mathrm{p}<0.01)$ terhadap daya hambat baik terhadap pertumbuhan bakteri $E$. coli maupun S. aureus. Data hasil pengujian daya hambat edible coating pati biji durian-kitosan yang ditambahkan ekstrak daun kesum pada konsentrasi yang berbeda terhadap pertumbuhan bakteri E. coli dan S. aureus disajikan pada Tabel 1. Tabel 1 menunjukkan bahwa daya hambat edible coating dengan penambahan ekstrak daun kesum terhadap bakteri S. aureus berkisar antara $3.432-4.344 \mathrm{~mm}$, sedangkan daya hambat terhadap bakteri E. coli berkisar antara 2.233-3.596 mm. Daya hambat edible coating terhadap bakteri $S$. aureus lebih besar dibandingkan dengan daya hambat terhadap bakteri $E$. coli, hal ini menunjukkan bahwa ekstrak daun kesum mengandung senyawa aktif yang lebih sesuai dengan bakteri gram positif dibandingkan dengan bakteri gram negatif. Sesuai dengan pernyataan Saroinsong et al. (2014) bahwa ekstrak Haliclona sp. lebih besar menghambat pertumbuhan bakteri S. aureus dibandingkan bakteri E. coli, hal itu menunjukkan bahwa ekstrak Haliclona sp. mengandung senyawa aktif yang lebih sesuai dengan bakteri gram positif dibandingkan dengan bakteri gram negatif.

Selain itu, bakteri S. aureus merupakan bakteri gram positif, sehingga lebih sensitif dibandingkan dengan gram negatif. Hal ini kemungkinan terjadi karena adanya perbedaan tingkat ketebalan struktur dinding sel dari masing-masing bakteri E. Coli merupakan bakteri gram negatif yang struktur dinding selnya terdiri dari tiga lapis, sedangkan bakteri $S$. aureus adalah bakteri gram positif yang berdinding sel berlapis tunggal (Pelczar dan Chan, 1988). Struktur dinding sel bakteri $S$. aureus yang berlapis tunggal dan relatif sederhana akan memudahkan masuknya zatzat yang dapat merusak sel bakteri, sedangkan bakteri E. Coli struktur dinding selnya berlapis tiga (Dewi dan Fawzya, 2006; Villanueva, 2018; Yang et al., 2018).

Gambar 1 menunjukkan bahwa terjadi peningkatan diameter zona hambat mulai dari edible coating dengan penambahan ekstrak daun kesum terendah $(0 \%)$ hingga tertinggi $(1.4 \%)$. Perlakuan 0\% (kontrol) ed- ible coating tanpa penambahan senyawa aktif ekstrak daun kesum juga memiliki daya hambat, hal itu disebabkan karena adanya kitosan dalam bahan komposit edible coating. Pernyataan Danggi (2008) menyatakan bahwa kitosan mempunyai sifat antimikroba, yang disebabkan karena adanya muatan positif pada gugus amino yang dapat berikatan dengan muatan negatif membran sel.

Kitosan yang berfungsi sebagai antibakteri memiliki sifat mekanisme penghambatan, dimana kitosan akan berikatan dengan protein membran sel, yaitu glutamat yang merupakan komponen membran sel. Selain berikatan dengan protein membran sel, kitosan juga berikatan dengan fosfolipid membran, terutama fosfatidil kolin, sehingga meningkatkan permeabilitas inner membran. Naiknya permeabilitas inner membrane akan mempermudah keluarnya cairan sel. Pada Escherichia coli, setelah 60 menit komponen enzim $ß$ galaktosidase akan terlepas. Hal ini menunjukkan bahwa sitoplasma dapat keluar sambil membawa metabolit lainnya, atau dengan kata lain mengalami lisis, yang akan menghambat pembelahan sel (regenerasi) dan akan menyebabkan kematian sel (Hargono dan Djaeni, 2010; Micali et al., 2018; Scepanovic dan Fernandez-Gonzalez, 2018).

Hasil penelitian Coma et al., (2002) menunjukkan bahwa kitosan kulit udang dapat menghambat pertumbuhan Listeria monocytogenes, sedangkan Damayanti et al. (2016) menyatakan bahwa kitosan mempunyai daya hambat yang lebih tinggi pada Escherichia coli (bakteri gram negatif) dibandingkan dengan Staphylococcus aureus dan Bacillus subtilis (bakteri gram positif). Devlieghere et al. (2004) juga menyebutkan bahwa kitosan lebih efektif menghambat pertumbuhan bakteri gram negatif dibandingkan bakteri gram positif.

Adanya zona hambat yang secara berangsur-angsur lebih tinggi mulai dari $0.20-1.40 \%$ dibandingkan dengan $0 \%$, hal itu karena terdapat kombinasi 2 jenis bahan aktif kitosan dan ekstrak daun kesum yang samasama mempunyai kemampuan menghambat pertumbuhan mikrobia. Penambahan ekstrak daun kesum jelas terlihat mempengaruhi aktivitas antimikroba dari kitosan, semakin tinggi penambahan ekstrak daun kesum, makin tinggi daya hambat. Sesuai dengan pernyataan Danggi (2008) bahwa penambahan bahan alami lain yang diketahui memiliki daya hambat mikroba secara 
tunggal berpotensi digunakan untuk meningkatkan kemampuan antimikroba kitosan. Pada penambahan ekstrak daun kesum $1.40 \%$ menghasilkan zona hambat yang paling besar karena mengandung senyawa aktif paling tinggi.

Senyawa aktif ekstrak daun kesum yang diketahui memiliki daya hambat mikrobia adalah senyawa golongan fenolik, terpenoid-steroid, flavonoid dan alkaloid (Wibowo, 2009) yang berfungsi sebagai antibakteri. Senyawa mayor minyak atsiri daun kesum menurut Fitriana et al. (2014) terdiri dari n-dodekanal 31\%, n-dekanal 16.88\%, n-dodekanol $6.12 \%$, 8-bromo tetrametil naftalen $4.63 \%$, Trans- $(\beta)$-caryopilen $3.37 \%$. Flavonoid mengakibatkan terjadinya kerusakan permeabilitas dinding sel bakteri, mikrosom, dan lisosom sebagai hasil interaksi antara flavonoid dengan DNA bakteri, sedangkan alkaloid memiliki kemampuan sebagai anti- bakteri. Mekanisme yang diduga adalah dengan cara mengganggu komponen penyusun peptidoglikan pada sel bakteri, sehingga lapisan dinding sel tidak terbentuk secara utuh dan mengakibatkan kematian sel (Dewi dan Fawzya, 2006; Alcorlo et al., 2017; Neelay et al., 2017; Bougault et al., 2018; Caveney et al., 2018).

\section{SIMPULAN}

Berdasarkan hasil penelitian dapat disimpulkan bahwa penambahan ekstrak daun kesum pada edible coating pati biji durian-kitosan berpengaruh sangat nyata terhadap daya hambat bakteri Escherichia coli dan S. aureus. Daya hambat ekstrak daun kesum terhadap S. aureus antara 3.432-4.344 $\mathrm{mm}$ dan terhadap bakteri E coli antara 2.233-3.596 $\mathrm{mm}$.

Tabel 1. Rata-rata daya hambat edible coating yang ditambahkan ekstrak daun kesum dengan konsentrasi yang berbeda

\begin{tabular}{|c|c|c|}
\hline \multirow{2}{*}{$\begin{array}{c}\text { Konsentrasi Ekstrak } \\
\text { Daun Kesum (\%) }\end{array}$} & $\begin{array}{c}\text { Daya Hambat Edible Coating dengan Ekstrak Daun } \\
\text { Kesum (mm) }\end{array}$ \\
\cline { 2 - 3 } & S. aureus $^{\text {Escherichia coli }}$ \\
\hline 0.00 & $3.432 \pm 0.158^{\mathrm{a}}$ & $2.233 \pm 0.085^{\mathrm{a}}$ \\
\hline 0.20 & $3.666 \pm 0.164^{\mathrm{ab}}$ & $2.557 \pm 0.287^{\mathrm{ab}}$ \\
\hline 0.40 & $3.702 \pm 0.332^{\mathrm{abc}}$ & $2.777 \pm 0.128^{\mathrm{b}}$ \\
\hline 0.60 & $4.083 \pm 0.290^{\mathrm{bcd}}$ & $2.746 \pm 0.155^{\mathrm{b}}$ \\
\hline 0.80 & $4.074 \pm 0.140^{\mathrm{bcd}}$ & $2.796 \pm 0.084^{\mathrm{b}}$ \\
\hline 1.00 & $4.128 \pm 0.109^{\mathrm{bcd}}$ & $2.802 \pm 0.216^{\mathrm{b}}$ \\
\hline 1.20 & $4.728 \pm 0.368^{\mathrm{cd}}$ & $2.834 \pm 0.094^{\mathrm{b}}$ \\
\hline 1.40 & $4.344 \pm 0.482^{\mathrm{d}}$ & $3.596 \pm 0.104^{\mathrm{c}}$ \\
\hline Keterangan: Huruf yang berbeda pada kolom yang sama menunjukkan adanya perbedaan nyata
\end{tabular}

Keterangan: Huruf yang berbeda pada kolom yang sama menunjukkan adanya perbedaan nyata

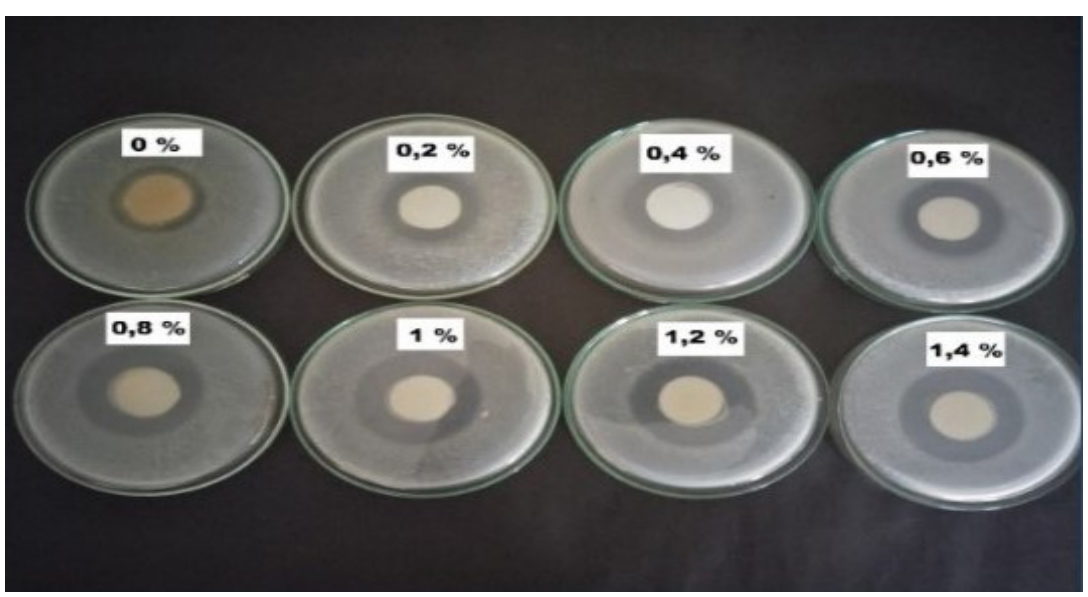

Gambar 1. Zona hambat edible coating dengan penambahan ekstrak daun kesum terhadap bakeri Staphylococcus aureus 
Jurnal Teknologi Pertanian Vol. 19 No. 3 [Desember 2018] 207-214

Pemanfaatan Kitosan Kulit Udang dengan Penambahan Ekstrak Daun Kesum [Lestari dkk]

\section{UCAPAN TERIMA KASIH}

Ucapan terima kasih disampaikan kepada Direktorat Riset dan Pengabdian Kepada Masyarakat, Direktorat Jenderal Penguatan Riset dan Pengembangan, Kementerian Riset, Teknologi dan Pendidikan Tinggi yang telah membiayai penelitian ini melalui Program Penelitian Produk Terapan Tahun 2017.

\section{DAFTAR PUSTAKA}

Alcorlo, -M., Martinez-Caballero, -S., Molina, -R., Hermoso, J, -A., 2017. Carbohydrate recognition and lysis by bacterial peptidoglycan hydrolases. Current Opinion in Structural Biology. 44, 87-100. https://doi.org/10.1016/j. sbi.2017.01.001

Amid, B, -T., Mirhosseini, -H., 2012. Optimisation of aqueous extraction of gum from durian (Durio zibethinus) seed: A potential, low cost source of hydrocolloid. Food Chemistry. 132(3), 12581268. https://doi.org/10.1016/j.foodchem.2011.11.099

Ban, -W., Song, -J., Argyropoulos, D, -S., Lucia, L, -A., 2005. Improving the physical and chemical functionally of starch derived films with biopolymers. Journal of Applied Polymer Science. 100(3), 2542-2548. https://doi.org/10.1002/app.23698

Bougault, -C., Ayala, -I., Vollmer, -W., Simorre, J, -P., Schanda, -P., 2018. Studying intact bacterial peptidoglycan by protondetected NMR spectroscopy at $100 \mathrm{kHz}$ MAS frequency. Journal of Structural Biology. https://doi.org/10.1016/j. jsb.2018.07.009

Caveney, N, -A., Li, F, -KK., Strynadka, N, -CJ., 2018. Enzyme structures of the bacterial peptidoglycan and wall teichoic acid biogenesis pathways. Current Opinion in Structural Biology. 53, 45-58. https:/ / doi. org/10.1016/j.sbi.2018.05.002

Chakravartula, S, S, -N., Cevoli, -C., Balestra, -F., Fabbri, -A., Rosa, M, -D., 2019. Evaluation of drying of edible coating on bread using NIR spectroscopy.
Journal of Food Engineering. 240, 2937. https://doi.org/10.1016/j.jfoodeng.2018.07.009

Chi, -S., Zivanovic, -S., Penfield , M, -P., 2006. Application of chitosan films enriched with oregano essential oil on bolognaactive compounds and sensory attributes. Food Science and Technology International. 12(2), 111-117. https://doi. org/10.1177/1082013206063845

Costa, -M, -J., Maciel, L, -C., Teixeira, J, -A., Vicente, A, -A., Cerqueira, M, -A., 2018. Use of edible films and coatings in cheese preservation: Opportunities and challenges. Food Research International. 107, 84-92. https://doi. org/10.1016/j.foodres.2018.02.013

Coma, -V., Martial-Cros, -A., Garreau, -S., Copinet, -A., Salin, -F., Deschamps, -A., 2002. Edible antimicrobial films based on chitosan matrix. Journal Food Science. 67(3), 1162-1169. https://doi. org/10.1111/j.1365-2621.2002.tb09470.x

Damayanti, -W., Rochima, -E., Hasan, -Z., 2016. Aplikasi kitosan sebagai antibakteri pada filet patin selama penyimpanan suhu rendah. JPHPI. 19(3), 321-328. https://doi.org/10.17844/ jphpi.2016.19.3.321

Danggi, E. 2008. Aplikasi Kitosan dengan Penambahan Esensial Oil Kunyit sebagai Pengawet dan Edible Coating Produk Tahu. Tesis. Sekolah Pascasarjana. IPB. Bogor

Dewi, A, -S., Fawzya, Y, -N., 2006. Kitosan oligosakarida: produksi dan potensinya sebagai antibakteri. Squalen. 1(1), 26-33. http://dx.doi.org/10.15578/ squalen.v1i1.75

Devlieghere, -F., Vermeulen, -A., Debevere, -J., 2004. Chitosan: antimicrobial activity, interactions with food components and applicability as a coating on fruit and vegetables. Food Microbiology. 21(6), 703-714. https://doi. org/10.1016/j.fm.2004.02.008

Fitriana, N., Rumayati., Sumartini, N., Jayuska, A., Syaiful, Harliya. 2014. Formulasi serbuk flavour makanan dari minyak atsiri tanaman kesum (Polygonum minus huds) sebagai penyedap makanan. Jurnal Aplikasi Teknologi Pangan. 3(1), 12-15. http://www.jatp.ift.or.id/ index.php/jatp/article/view/37/47

Hajji, -S., Younes, -I., Affes, -S., Boufi, -S., Nasri, -M., 2018. Optimization of the 
formulation of chitosan edible coatings supplemented with carotenoproteins and their use for extending strawberries postharvest life. Food Hydrocolloids. 83, 375-392. https:// doi. org/10.1016/j.foodhyd.2018.05.013

Hardjito, L., 2006. Aplikasi kitosan sebagai bahan tambahan makanan dan pengawet. Dipresentasikan di Seminar Nasional Kitin Kitosan. IPB, Bogor, p. 1

Hargono, Djaeni, M., 2010. Pemanfaatan kitosan dari kulit udang sebagai pelarut lemak. Dipresentasikan di Seminar Nasional Teknik Kimia Indonesia, IPB, Bogor

Ho, L, -H., Bhat, -R., 2015. Exploring the potential nutraceutical values of durian (Durio zibethinus L.) - An exotic tropical fruit. Food Chemistry. 168, 8089. https://doi.org/10.1016/j.foodchem.2014.07.020

Lee, S. -T., Mi, F, -L., Shen, Y, -J., Shyu, S, S., 2001. Equilibrium and kinetic studies of copper(II) ion uptake by chitosantripolyphosphate chelating resin. Polymer. 42(5), 1879-1892

Lestari, R, B., Maherawati. 2014. Pembuatan Plastik Biodegradable dari Komposit Pati Biji Durian-Kitosan serta Aplikasinya sebagai Bahan Pengemas Buah. Laporan Penelitian. Universitas TanjungPura, Kalimantan Barat

Maizura, -M., Fazilah, -A., Norziah, M, -H., Karim, A, -A., 2008. Antibacterial activity and mechanical properties of partially hydrolyzed sago starch-alginate edible film containing lemon grass oil. J. Food Sci. 72(6), 324-330. https:// doi. org/10.1111/j.1750-3841.2007.00427.x

Micali, -G., Grilli, -J., Marchi., -J., Osella, -M., Lagomarsino, M, -M., 2018. Dissecting the control mechanisms for DNA Replication and cell division in E. coli. Cell Report. 25(3), 761-771. https://doi. org/10.1016/j.celrep.2018.09.061

Neelay, O, -P., Peterson, C, -A., Snavely, M, -E., Brown, T, -C., TecleMariam, A, -F., Campbell, J, -A., Blake, A, -M., Schneider, S, -C., Cremeens, M, -E., 2017. Antimicrobial peptides interact with peptidoglycan. Journal of Molecular Structure. 1146, 329-336. https://doi. org/10.1016/j.molstruc.2017.06.018

Pelczar, M, J., Chan, E, C, S., 1988. DasarDasar Mikrobiologi. Universitas Indonesia, Jakarta
Permatasari, G, A, A, -A., Besung, I, N, -K., Mahatmi, -H. 2013. Daya hambat perasan daun sirsak terhadap pertumbuhan bakteri Escherichia coli. Indonesia Medicus Veterinus. 2(2), 162 - 169. https://ojs.unud.ac.id/index.php/imv/ article/view/5524

Pudil, -F., Wijaya, -H., Janda, -V., Volfova, -J., Valentova, -H., Pokorny, -J., 1998. Changes in Citrus hystrix oil during autooxidation. Development in Food Science. 40, 707-718. https://doi. org/10.1016/S0167-4501(98)80091-5

Rojas-Grau, M, A., Soliva-Fortuny, R., Martin-Belloso, O. 2009. Edible coatings to incorporate active ingredients to fresh cut fruits: a review. Trends in Food Science \& Technology. 20(10), 438-447. https://doi.org/10.1016/j. tifs.2009.05.002

Rahayu, L, -L., Purnavita, -S., 2007. Optimasi pembuatan kitosan dari kitin limbah cangkang rajungan (Portunus pelagicus) untuk adsorben ion logam merkuri. Reaktor. 11(1), 45-49. https:/ / doi.org/10.14710/reaktor.11.1.45-49

Saroinsong, M, S., Kandou, F, E, F., Papu, A., Singkoh, M, F, O., 2014. Uji daya hambat ekstrak metanol beberapa jenis Porifera terhadap bakteri Escherichia coli dan Staphylococcus aureus. Jurnal MIPA. 3(2), 129-133. https:// ejournal. unsrat.ac.id/index.php/jmuo/article/view/5989

Scepanovic, -G., Fernandez-Gonzalez, -R., 2018. Oriented cell division: the pull of the pole. Development cell. 47(6), 686687. https://doi.org/10.1016/j.devcel.2018.11.040

Utami, R., Kawiji, Khasanah, L.U., Narinda, A.H. 2015. Pengaruh oleoresin daun jeruk purut (Citrus hystrix DC) pada edible coating terhadap kualitas sosis sapi beku. Journal of Agroindustrial Technology. 25(2), 116-124. http://journal.ipb.ac.id/index.php/jurnaltin/article/view/10856

Villanueva, -L., 2018. Engineering E. coli to Have a Hybrid Archaeal/Bacterial Membrane. Trends in Microbiology. 26(7), 559-560.https://doi. org/10.1016/j.tim.2018.05.003

Wibowo, M, -A., 2009. Uji anti mikroba fraksi metanol dan dietil eter daun tanaman kesum polygonum minus huds. Jurnal Agripura. 2(4), 26-31 
Jurnal Teknologi Pertanian Vol. 19 No. 3 [Desember 2018] 207-214

Pemanfaatan Kitosan Kulit Udang dengan Penambahan Ekstrak Daun Kesum [Lestari dkk]

Yang, -Z., Choi, -H., Weisshaar, J, -C., 2018. Melittin-Induced Permeabilization, Resealing, and Re-permeabilization of E. coli
Membranes. Biophysical Journal. 114(2), 368-379. https://doi.org/10.1016/j. bpj.2017.10.046 